Vol. 2, No. 1, 2017

\title{
BIOTECHNICAL COMPONENTS OF CYBER-PHYSICAL SYSTEMS
}

\author{
Leonid Berezko, Serhii Sokolov \\ Lviv Polytechnic National University, 12, S. Bandera str., Lviv, 79013, Ukraine \\ Author e-mail: leonid.berezko@gmail.com
}

Submitted on 01.02.2017

(C) Berezko L., Sokolov S., 2017

Abstract: We synthesized the general structures of biomedical electric impedance biotechnical systems as a part of cyber-physical systems and propose methodological recommendations on the electric impedance equipment development.

Index Terms: biomedical electric impedance, biotechnical systems, cyber-physical systems.

\section{INTRODUCTION}

Recently there has been a significant growth of interest to the concept of cyber-physical systems $(\mathrm{CPhS})$ development for diverse spheres of human activity. $\mathrm{CPhS}$ 's are considered as intellectual systems containing physical objects, external devices, processors, network equipment. The main purpose of creating CPhS's is a real-time control over the behavior of physical objects as components of such systems. These are systems in which interaction between cyber tools (measuring, computing, communication, control and execution ones) and physical processes in arbitrary objects take place $[15,16]$.

The idea of spreading the $\mathrm{CPhS}$ concept on biomedical industry seems promising. In such $\mathrm{CPhS}$ 's physical objects are biological objects (BO) from the simplest to human beings. Monitoring of BOs behavior with cybernetic methods, automatically receiving their parameters and characteristics in real time provide more reliable interaction with BOs. We should note that peculiarities of use and physical (biophysical) features of BOs define the peculiar properties of design and development of particular $\mathrm{CPhS}$ 's.

Wide-spread concept of biotechnical systems (BTS's) [10-13], which include the necessary tools and means of research and the BO itself, allows to consider BTS as a standalone measurement and computational component of $\mathrm{CPhS}$, located within the $\mathrm{CPhS}$ structure between the physical world and communication environment.

In accordance with the multi-level basic $\mathrm{CPhS}$ platform [15], the behavior of its elements at any level should be credible and predictable. If this requirement is not fully implemented, then the means of next (upper) level should compensate these shortcomings. BTS as a component of $\mathrm{CPhS}$ contains embedded computer tools performing the functions of local control, preprocessing of the data acquired, presenting this data as required for transmission and perception by the upper levels of $\mathrm{CPhS}$. Regulation algorithms of information flows in the communications environment between $\mathrm{BO}$ and $\mathrm{CPhS}$ users ensure the real-time operation during the monitoring of $\mathrm{BO}$ [16].

Despite the significant advances of global electronic biomedical instrumentation industry and creation of BTS's of diverse purposes, considering BTS as a component of $\mathrm{CPhS}$ it provides new opportunities.

The development of biology and medicine necessitate the search of instrumental, objective means of interaction with BOs. We should note that during the modernization and improvement of existing BTS's the electronic components are updated, circuit solutions and software are revised, however the functional principles as well as the parameters of primary data sensors undergo no significant changes. In particular this concerns BTS's which use bioelectrical impedance method in the study of BOs. Please, note that the tasks of measuring the impedance of non-biological objects are discussed in detail in [17]. Design of BTS as a component of $\mathrm{CPhS}$ is based on biomedical electroimpedance measurements $[1-4,5,6]$, has its own features and represents a significant interest.

\section{ANALYSIS OF RECENT PUBLICATIONS}

Considering electronic engineering devices of biomedical appointment as BTS is quite popular and is reflected in papers related to the development of complex electromagnetic therapy systems [7] and sensors for pulse diagnosis [8]. There are also studies on the possibilities of BTS's synthesis in order to replace organs and functions on human body with artificial entities [9]. Works [10-13] show significant steps towards the analysis of design features of biomedical electroimpedance equipment (BMEIE) as BTS. It has been shown that BMEIE in general can be represented by one of the three BTS structures. The first structure determines informative biophysical parameters. The second one allows to convert the measured biophysical parameter value into BO's physiological characteristics. The third structure solves the tasks of the first two in case of external influence on the BO.

In addition to mandatory data proving the expediency of certain development, its verification and analysis of the advantages and possible disadvantages in comparison with analogues, biomedical devices of any structure must meet specific unique requirements, prepared for this particular device. 


\section{RESEARCH GOAL}

Research goal of the paper is to analyze the features of design of BMEIE as an integrated BTS as well as a part of $\mathrm{CPhS}$.

\section{RESULTS OF THE STUDY}

Fig. 1 represents the generalized structure of BTS of obtaining diagnostic information by electrical impedancemetry.

The main feature of BMEIE consists in cooperation of technical measuring device and $\mathrm{BO}$. On the edge between electrode and $\mathrm{BO}$ there occurs a complex phenomenon called polarization. Measurement error caused by it depends on the mode of measurement and electrode material. In this regard, when using bioelectrical impedance measurement method, selection of frequency and current density as well as design of electrodes and their connection system (unipolar, bipolar or tetrapolar) are crucial for all the BTS structures. Random nature of polarization error requires experimental study of electrodes functioning in actual contact with BOs. This foremost concerns the stability of repeated measurements results and their drift.

The complexity of the BMEIE metrology consists in the fundamental impossibility of selecting an exemplary BO. Thus, evaluation of measurement error in such a case can only be made by modelling of BO.

Features considered are key ones when designing BMEIE according to the first BTS structure (Fig. 1, a).

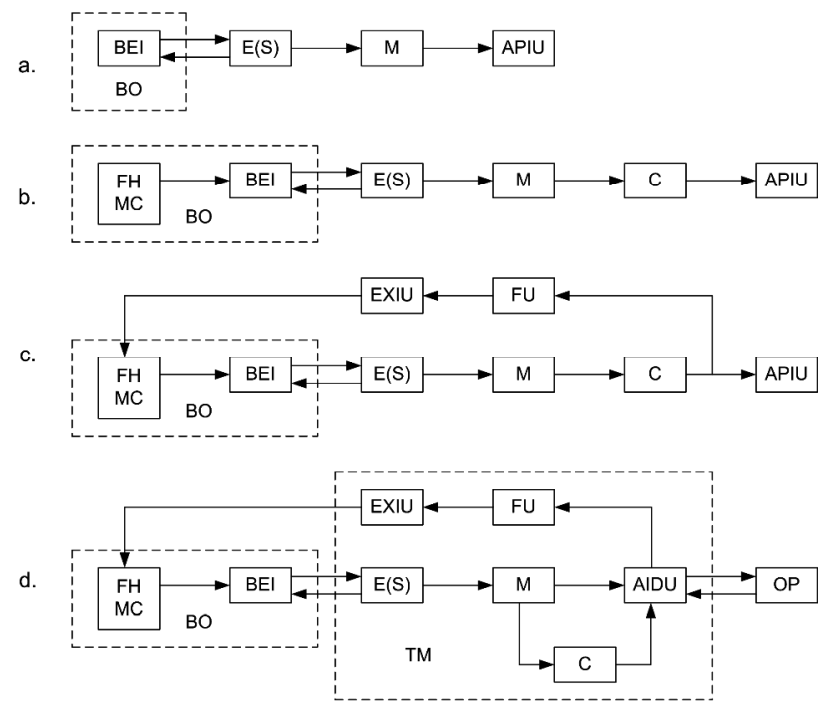

Fig. 1. Basic generalized BTS structures of information acquisition by electrical impedancemetry

Conventions: BEI - bioelectrical impedance; FH physiological characteristic; MC - morphological characteristic; BO - biological object; E - electrodes; $\mathrm{S}$ - sensor; $\mathrm{M}$ - electrical impedance meter; $\mathrm{C}$ - converter; APIU - automatic presentation of information unit; EXIU - external influences unit; FU - feedback unit; AIDU - analysis and information display unit; OP interface unit (the operator); TM - technical means.
When designing serial medical equipment developers must convert the BEI value into FH. For this type of BTS structure (Fig. 1, b) everything related to the previous one is also true. In addition, two elements are added to it: FH and converter $\mathrm{C}$ with the characteristics of transformation:

$\mathrm{FH}=\mathrm{F}(\mathrm{BEI})$,

where FH - physiological characteristic and BEI bioelectrical impedance.

An example of the second type of BTS structure (Fig. 1, b) is a device that determines the volume of packed red cells in blood (hematocrit, Ht) by the value of electrical impedance. $\mathrm{Ht}$ is one of the most important indicators of blood. It is used in the calculation of the main parameters of the circulatory system, for evaluation of blood loss, control of infusion therapy etc.

There are studies that prove sufficiently close connection of electrical impedance of blood $Z_{b 1}$ with the value of Ht. So, the formula obtained by the authors as a result of experimental studies outlined in [3], is as follows:

$$
\mathrm{Z}_{\mathrm{bl}}=\mathrm{A}+\mathrm{B} \cdot \mathrm{Ht},
$$

where $Z_{b l}$ - electrical impedance of blood; A, B coefficients that determine the age and sex of patients.

The correlation coefficient between the data obtained by electric impedancemetry and by using a centrifuge, used in the study for comparison, was within $0,88-0,96$.

Tests have shown the benefits of electrical impedance method for determining $\mathrm{Ht}$ in specific circumstances, such as in disaster medicine.

When using an external influence on the investigated physiological process in order to stimulate its display the external influences unit (EXIU) is attached (Fig. 1, c). An example of such a structure is a device for determining tissue clearance of liquids and gases [13].

When using an external action as a therapeutic one, one must include a feedback unit (FU) in the BTS structure (Fig. 1, c). Due to general biological effect of accommodation, e.g. during nerve stimulation or defibrillation, BO changes its properties. Change of electrical impedance and its components is a display of this phenomenon $[10,11]$. Feedback makes it possible to automatically and quickly optimize the intensity and form of the influence signal.

When using the external action as a therapeutic in the BPS structure must enter feedback unit (BFB) (Fig. 1, b). Due to general biological effect of accommodation, such as neurostimulation or defibrillation, because there are changes its properties. A manifestation of this phenomenon is the change in electrical impedance and its components $[10,11]$. Feedback makes it possible to automatically and quickly optimize signal intensity and form of influence. Electrical stimulation devices of certain type are based on this principle [10].

The specificity and complexity of BMEIE metrological support is caused by fundamental impossibility of selecting an exemplary BO. Therefore, assessment of measurements can be carried out only by 
the modelling of living biological tissue, precisely the passive electrical properties of the BO tissue, which are undergoing change according to the known law under the change of physiological (or morphological) characteristic which is studied.

The specificity and complexity of processing the information obtained during the study of $\mathrm{BO}$ often represent a major challenge in the equipment development and results interpretation. This is especially important in complex technical equipment such as impedance tomograph. Due to extensive use of microprocessor technology in biomedical equipment, the analysis and information display unit (AIDU) gains significant importance (Fig 1, d). In addition to the standard functions of displaying information, implementing interface with operator and controlling other BTS units, it can serve as EXIU and FU as well as perform intellectual information processing, that can not be done by other means.

We must also consider the use of BMEIE as a part of $\mathrm{CPhS}$ working in real time. In this case the OP is an interface unit that implements protocols of interlayer exchange of information in $\mathrm{CPhS}$, including the operator.

Let us consider the design features of structure displayed on Fig. 1, d on the example of development of electrical impedance method and technical means of tissue clearance of liquids study. Tissue clearance (TC) is the release of a piece of biological tissue from the previously injected liquid (or gas). Study of the TC of liquids belong to one of the few opportunities to obtain information on microcirculation, i.e. metabolism at the capillary level. The study of TC dynamics is to monitor the biophysical parameter, the change of which over time corresponds to the dynamics of the process. In our case, this parameter is the electrical impedance.

The main advantages of electrical impedance method over the most widely used Kety method [14] are, above all, an absence of radioactive materials, a significant increase in the number of investigated solutions, opportunities to record process dynamics and to perform multiple studies.

Given the need for implementation of the above mandatory operations, let us synthesize the BTS designed to study the TC dynamics of liquids, i.e. let us specify the composition of elements and their interaction for the BTS structure on Fig. 2. In this case, an introduction of liquid unit (ILU) is an EXIU.

The key issue in the development of technical means of TC research is sensor (S), which allows simultaneously to introducing fluid into the tissue and measuring the TC in the input point. Sensor with two needle electrodes fixed on dielectric holder satisfies these requirements. The working electrode is hollow and connected to the ILU.

To describe patterns of TC we developed a mathematical model in which the volume of biological tissue to be tested is displayed in the form of interconnected reservoirs (Fig. 3).
Unlike the Kety model [14], the proposed model takes into account the impact of liquid injection mode on TC and considers two physiological components of TC: capillary blood flow and liquid distribution in surrounding intercellular substance.

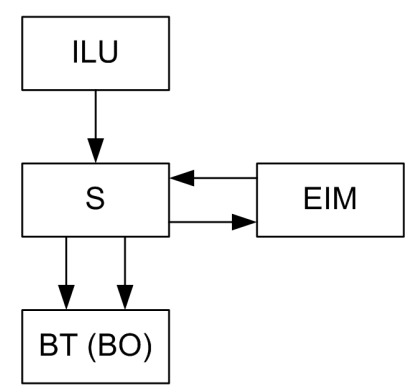

Fig. 2. BTS study of fluids' TC by electric impedance method Conventions: ILU - introduction of liquid unit, $S$ - sensor, EIM - electric impedance meter, BT $(B O)$ - biological tissue (biological object)

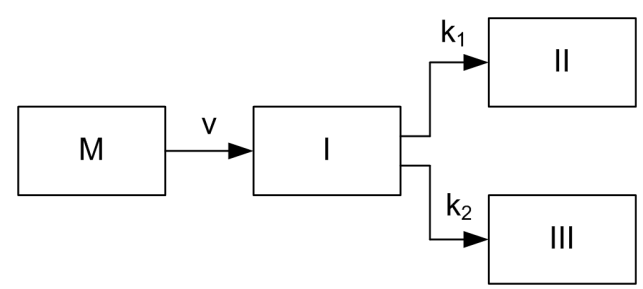

Fig. 3. Reservoirs of mathematical model of liquids' TC

Conventions: I - tank that meets the test volume of tissue in which the liquid is injected; II - reservoir corresponding to blood capillaries; III - tank that meets intercellular substance that surrounds injected liquid; $\mathrm{M}$ - the amount of fluid that is injected into the tissue $(\mathrm{ml}) ; \mathrm{v}$ - speed of liquid injection $(\mathrm{ml} / \mathrm{s}) ; \mathrm{k}_{1}-$ constant of fluid resorption by blood capillaries (1/s); $\mathrm{k}_{2}-$ constant of fluid resorption in the surrounding intercellular substance $(1 / \mathrm{s})$.

Studying the two phases of the process (liquid injection phase and directly extracting liquid from tissue) we got a system of equations describing the TC considering the injection speed and the mass of liquid and allowing to determine the amount of substance in the test area of tissue over time [12]:

$$
\left\{\begin{array}{ccc}
m=\frac{v}{k_{1}+k_{2}}\left(1-e^{-\left(k_{1}+k_{2}\right) t_{T}}\right) & \text { if } & t_{T} \leq \frac{M}{v} \\
m=M \cdot e^{-\left(k_{1}+k_{2}\right)\left(t_{T}-\frac{M}{v}\right)} & \text { if } & t_{T}>\frac{M}{v}
\end{array}\right.
$$

where: $M-$ the amount of liquid that is injected into the tissue $(\mathrm{ml}) ; v-$ speed of the liquid injection $(\mathrm{ml} / \mathrm{sec})$; $k_{1}$ - constant of fluid resorption by blood capillaries $(1 / \mathrm{s}) ; k_{2}-$ constant of fluid resorption into the surrounding intercellular substance $(1 / \mathrm{s}) ; m$ - current amount of liquid in the tank $\mathrm{I}(\mathrm{ml}) ; t_{T}$ - current time (s).

The developed model allowed to calculate the theoretical dependence of information parameter of clearance (time of half-clearance, $\mathrm{T}_{50} \%$ ) on the mass and 
speed of liquid injection. To select the operating pressure of liquid injection we experimentally determined the main patterns of liquids absorption by biological tissues. E.g. we determined the time of absorption of $0.1 \mathrm{ml}$ $0.9 \% \mathrm{NaCl}$ solution and distilled water in a pressure range of $15-45 \mathrm{~cm}$, water gauge. Based on the findings obtained from the analysis of the developed mathematical model and experimental data we calculated the coefficients of resorption and absorption of $0.9 \%$ $\mathrm{NaCl}$ solution and distilled water.

Wide range of testing solutions and the ability to determine the TC of gases give the possibility of using electric impedance method of microcirculatory processes study in experimental biology and medicine.

Thus, presentation of BMEIE as BTS, which combines BO, TM and OP in one structure (Fig. 1, d), determines the specific features of such BTS development and its place in the structure of the corresponding $\mathrm{CPhS}$.

We have a relationship of two generalized structures (Fig. 4): BTS (Fig. 1, d) and CPhS [16]. In this case, the object from "physical world" is the biological object (BO).

An important feature of the proposed $\mathrm{CPhS}$ is interaction with the human operator. When using $\mathrm{CPhS}$ in medical practice, excluding such interaction is not an option, as the final evaluation of the result as well as monitoring of automatic execution of certain actions (with the possibility of interference) is performed by doctor. In order to perform this, the appropriate interface means should be provided.

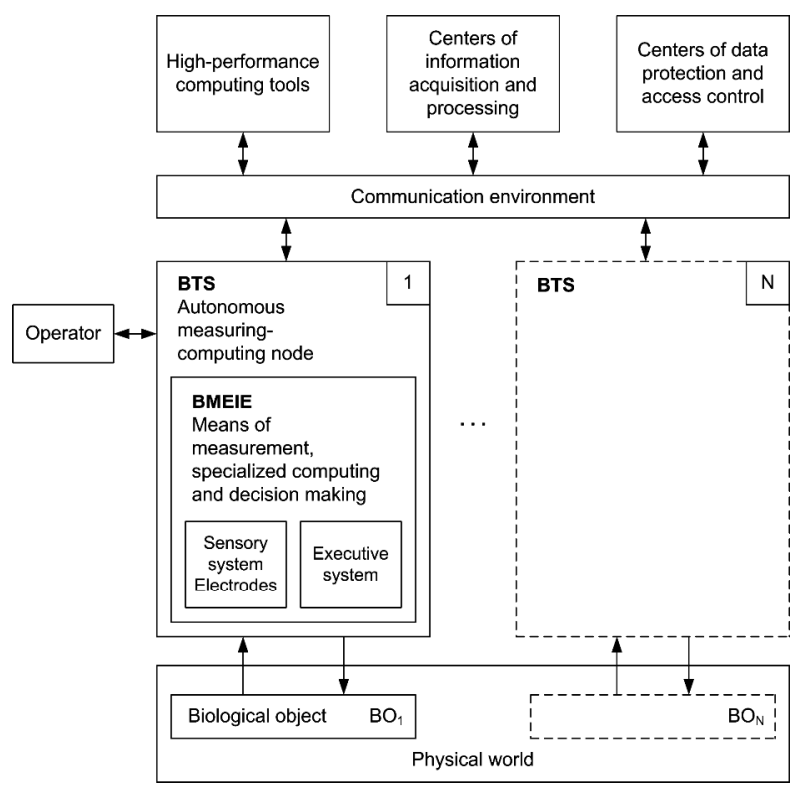

Fig. 4. Biotechnical medical system in the structure of cyber-physical system

\section{CONCLUSIONS}

Synthesized generalized structures of biomedical electric impedance BTS allow to formulate and solve problems of designing such BTSes as $\mathrm{CPhS}$ components.
The sequence of BTS development is determined by its characteristics. Complex design activities must begin with developing of a structure and analyzing of its components. Interaction features between biological and technical components set a list of experimental (especially biophysical) and theoretical studies that go along with technical implementation phases.

In terms of metrology, feature of developing BTS on the BMEIE basis is the inability to have an exemplary BO. Errors in BMEIE arise as a result of interaction between measurement sensors and $\mathrm{BO}$ as well as biophysical parameters recalculation in $\mathrm{FH}$.

Features of construction of BPS based BMEA terms of metrology is the inability to have an exemplary BU. Errors in BMEA arise as a result of interaction measurement sensors and buoys and biophysical parameters in terms of FH. Determining the reliability and equipment error is possible only by modeling of BO.

Using BTS as a $\mathrm{CPhS}$ component puts additional requirements for organization of information exchange protocols between $\mathrm{CPhS}$ systems in real time.

Theoretical analysis of the structure of biomedical purpose $\mathrm{CPhS}$ (Fig.4) and its practical implementation are relevant to experimental and practical medicine as well as other areas related to BO. The most important issues are the mutual influence of components in such $\mathrm{CPhS}$, functioning in automatic mode and enabling human operator intervention (doctor or researcher).

\section{REFERENCES}

[1] Abakumov V. G., Ribin O. I., Svatosh J. Biomedichni signaly. Genezis, obrobka, monitoring. K.: Nora-print, 2001, 516 s.

[2] Berezko L. O., Smerdov A. A., Sokolov S. Ye. Mozhlivosti zastosuvannia bioelektroimpedansometrii dlia doslidzhennia stanu mikrotsirkuliatsii.. Elektronika i sviaz, 2011, No. 2, s. 101-105.

[3] Smerdov A. A., Sokolov S. Ye., Smerdova T. A. Elektroimpedansnyi metod doslidzhennia mikrotsirkuliatsii $\mathrm{u}$ tvaryn. Visnik Poltavskoi derzhavnoi agrarnoi akademii, 2010, No. 1, s. 151-153.

[4] Smerdov A. A., Sokolov S. Ye., Smerdova T. A. Vykorystannia pasyvnykh elektrychnykh parametriv biologichnykh tkanyn u silskomu gospodarstvi. Visnik Poltavskoi derzhavnoi agrarnoi akademii, 2011, No. 1, s. 142-147.

[5] Akhutin V. M. Bionicheskiie aspekty sinteza biotechnicheskikh system. V sb.: Informatsionnyie materialy: kibernetika. M.: Sov. Radio, 1976, No. 4, s. 92-97.

[6] Dzhons Dzh. K. Metody proektirovaniia. M.: Mir, 1986, 326 s.

[7] Berkutov A. M., Zhulev V. I., Kuraiev G. A., Proshin E. M. Sistemy kompleksnoi elektromagnitoterapii. M.: Laboratoriia Bazovykh Znanii, 2006, 376s.

[8] Smerdov A. A., Storchun Ie. V. Biomedychni vymiriuvalni peretvoriuvachii. Lviv: Kalvariia, 1997, $112 \mathrm{~s}$.

[9] Mustetsov N. P., Beletskii N. I., Katrich V. A. Meditsinskiie elektronnyie sistemy. Kharkov: KhNU im. V. N. Karazina, 2008, 248 s.

[10] Sokolov S. Application of Bioimpedancemetry Method for Analysis of Microcirculatory Parameters. International Conference "Modern Problems of Radio Engineering, Telecommunications and Computer Science", Lviv Polytechnic National University, 2010, p. 138.

[11] Sokolov S. Osnovniie svoistva biotekhnicheskich sistem. Materialy XII Mizhnarodnoi naukovo-praktychnoi konferentsii "Suchasni informatsiini ta elektronni technologii", Odessa, 2011, s. 340.

[12] [Berezko L., Sokolov S. The systems approach to the development of electronic biomedical equipment. Advanced 
Computer Systems and Networks: Design and Application, Proceedings of the 6-th International Conference ACSN-2013, Lviv, pp. 38-40.

[13] Sokolov S. Ie. Biofizyka v biotekhnicheskikh sistemach. Materialy II Mezhdunarodnoi nauchno-technicheskoi konferentsii "Sovremennyie problemy fiziki, khimii i biologii. FizKhimBio-2013", Sevastopol, 2013, s. 133-134.

[14] Kety S. S. Measurement of regional circulation by the local clearance of radioactive sodium. American Heart Journal, 1949, No. 3, pp. 321-328.

Leonid Berezko, Ph. D., Assoc.

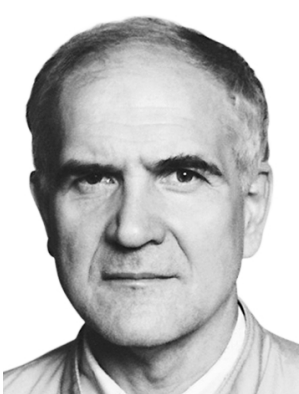

Prof. at Computer Engineering Department of Lviv Polytechnic National University. Areas of scientific and engineering research: computer systems of medical and technical diagnostics, sensor and specialized computer networks. Author of more than 70 scientific works.
[15] Melnik A. O. Kiberfizichni systemy: problemy stvorennia ta napriamy rozvitku // Visnik Natsionalnogo universitetu "Lvivska politekhnika". - 2014. - No. 806: Kompiuterni systemy ta merezhi. - s. 154-161.

[16] Anatoliy Melnik. Cyber-physical systems multilayer platform and research framework. Advances in cyber- physical systems. Volume1.Number1,2016, pp. 1-6.

[17] Pokhodylo Ie. V., Khoma V. V. Vymiriuvachi CLR z peretvorenniam "imitans-napruga". Monografiia. - Lviv: Lvivska politechnika, 2011. - $292 \mathrm{~s}$.

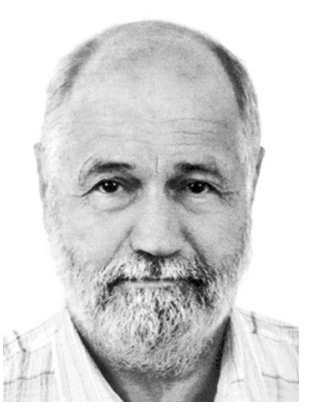

Serhii Sokolov graduated from Lviv Polytechnic with a major in radio engineering and finished his Ph. D. studies in biophysics at Bogomoletz Institute of Physiology, Kyiv. Areas of research: relationship between biophysics and medical electronic engineering. Author of more than 100 scientific works. 